食道浸潤胃癌における横隔膜合併切除の臨床的意義

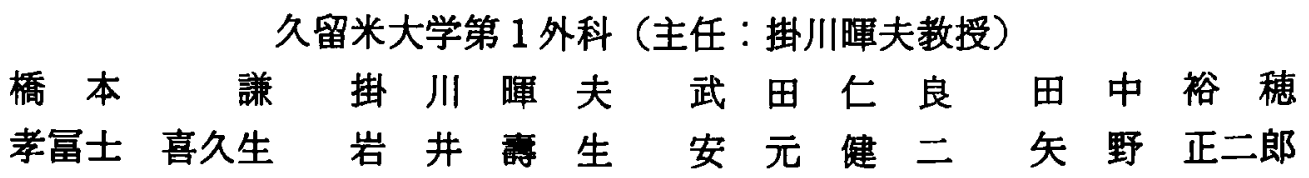

解剖学的に噴門部の後壁は無㢡膜野になっており横隔膜線維野と接することからこ の領域で壁外に增殖した癌隀の手術では根治性を得る為に横隔膜合併切除が必要なこと あ稀ではない.教室では1985年より食道浸潤胃癌のうち肉眼的㢡膜浸潤陽性で遠隔転移， 播種性転移を認めない症例を対象に左開胸下に片側横隔膜広範合併切除を行ってきたの でその治療成績について報告する. 1976年から1988年までに切除した CE 癌は111症例で 到達経路別では開胸開腹, 胸骨綎切：77例, 開腹のみ34例であった。左開胸開腹例の5 ち横隔膜合併切除は22例に施行し，横隔膜部分切除，残胃癌，多発癌を除く17例につい て手術成績を検討した。開胸合併切除例（合切例）の 2 生率は $69.9 \%$ ，開胸非合切例(非 合切例) 8.4\%であった. PS (+) 群に校ってみると合切例 $64 \%$, 非合切例 $41.8 \%$ であっ た. stage 別では stage IVで開胸合切例55.6\%, 開胸非合切例12.5\%と明らかな差がみ られた.

莱引用語：胃癌, 横隔膜, 合併切除

\section{緒 雼}

食道，胃接合部に発生または浸潤した胃癌は同領域 が胸腹境界にあたることから，進展範囲も多岐にわた り手術手技についても多くの問題を抱えている。こと に豊富なリンバ網をむつ横隔膜はこの領域に近接して いるにす拘わらず外科治療の対象臓器として取り扱わ れることは少なかった。しかし解剖学的には綎隔胸膜 と腹膜の間隚にあたる裂孔部周辺で壁外に増殖した癌 腫は，容易に横隔膜へ波及していくことが考えられる. 今回われわれはこれまで報告してきた動物実験結 果12)を踏主光，食道漫潤胃癌17症例に対する横隔膜合 併切除の治療成績を検討したので報告する.

\section{対象と方法}

\section{1. 对象症例}

1976年から1988年まで教室で切除した胃癌総数は 1,308 例で食道浸潤胃癌（以下 $\mathrm{CE}$ 癌）は111例であっ た. $\mathrm{CE}$ 癌のアブローチ別症例数は開胸開腹が73例と 最も多く，胸骨綎切開 4 例，開腹のみ34例であった。 左開胸開腹例の5ち可及的左側横隔膜合併切除（以下 合切例とする）は1985年から1988年までに17症例に施

1990 年 5 月29日受付 1991 年 1 月 9 日採用
行した.なお゙合切例の適応は肉眼的に肝転移，腹膜播 種性転移のない㢡膜浸潤陽性胃癌とした，本稿では左 開胸開腹例の5ち合切例17例, 横隔膜非合併切除例(以 下非合切例とする）56例の治療成績を比較検討した。 本文中の用語は胃癌取り扱い規約 ${ }^{3}$ に準し，生存曲線 は Kaplan-Meyer 法に上り求め曲線間の有意差は

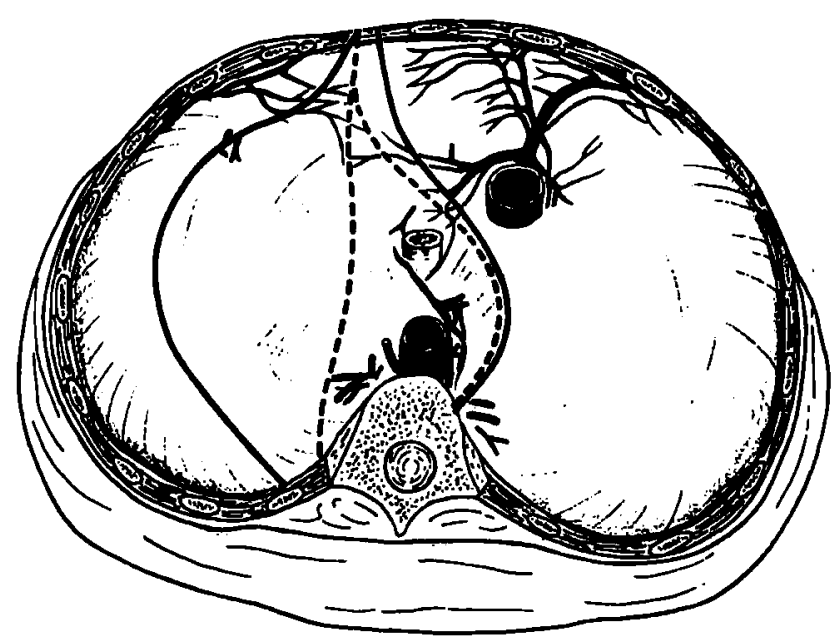

图 1 合併切除する模隔膜切淮腺 一：直接浸潤例など広背筋弁による再建を要する広籍 囲横隔膜合併切除の切離線。… : 通常の横隔膜合併切 除の切離線 
generalized wilcoxon test で検定した。

\section{2. 模隔膜合併切除術式と切除範囲}

横隔膜合併用切除範囲は癌腫が明らかに横隔膜へ漫 潤ないし転移していると診断した場合图 1 に実線で示 した広範囲切除，また肉眼的に横隔膜への浸潤ないし 転移がないと診断した症例では破線で示した裂孔から 約 $5 \mathrm{~cm}$ の範囲で横隔膜脚を含め合併切除した。合切後 の再建法は横隔膜弛緩症ないしは麻疸に利用される術 式()5)で切除範囲が小さい場合は再繾合ないしは䋖縮, 切除範用が大きい場合は, Rives 法5すなわち厇背筋の 有茎筋肉弁で横隔膜を形成する方法を採用している。

\section{成 綡}

\section{1. 模隔腊合併切除例の臨床病理}

下部食道, 胃上部，横隔膜を一体化した“姿造り” 摘出固定標本の全割切片を作成し鏡顕的に観察した （図 2). 横隔膜直接浸潤と横隔膜壁内転移の関保をみ ると直接浸潤がみられなかった11例のらち2 例 (18.2\%)に壁内転移を認め，直接浸潤がみられた 6 例 では 4 例 $(66.7 \%)$ に壁内転移を認めた。横隔膜壁内 転移を認めた 6 例の肉眼型は Borrmann 3 型, 組織型 は低分化型腺癌が圧倒的に多くみられた，n因子別で は $n_{4}$ 症例すなわちNo. 16 (大動脈周囲リンパ節) 転移 が 6 例中 4 例と多くみられた。 また原発巣の食道漫潤 距離は $1.5 \mathrm{~cm}$ から $5.3 \mathrm{~cm}$ (平均 $3.4 \mathrm{~cm}$ ) で壁内転移を認

\section{表 1 栱隔膜壁内転移淂性例の監床病理学的所見}

\begin{tabular}{|c|c|c|c|c|c|c|}
\hline \multirow{2}{*}{ 症例 } & \multicolumn{6}{|c|}{ 横隔膜壁内枟移陽性例 } \\
\hline & I & II & III & N & v & v \\
\hline 肉眼型 (Borrmann) & 3 & 3 & 3 & 3 & 3 & 4 \\
\hline 組縺型 & por & tub $_{2}$ & por & por & por & por \\
\hline n-number & $\mathrm{n}_{4}$ & $\mathrm{n}_{1}$ & $\mathbf{n}_{\mathbf{4}}$ & $\mathbf{n}_{2}$ & $\mathbf{n}_{4}$ & $\mathrm{n}_{4}$ \\
\hline 食道漫潤距離 $(\mathrm{cm})$ & 5.3 & 1.5 & 3.1 & 3.5 & 3.1 & 3.7 \\
\hline 壁内転移部位 & 両側 & 腹胫側 & 胸脭側 & 腹腔側 & 腹胵側 & 両側 \\
\hline 壁内転移距離 $(\mathrm{cm})$ & 3.6 & 3.2 & 7.0 & 3.0 & 2.5 & 5.2 \\
\hline
\end{tabular}

めなかった11例の食道漫潤距離 $2.7 \mathrm{~cm}$ と比較して差 はなかった。横隔膜壁内転移様式はリンバ槽もしくは リンバ管に限局するもの 4 例，びまん浸潤したすの 2 例であった。転移部位は胸腔側 1 例, 腹腔側 3 例, 两 側 2 例で食道裂孔部から横隔膜末梢への距離は $2.5 \mathrm{~cm}$ から $7 \mathrm{~cm}$ (平均 $4.1 \mathrm{~cm}$ ) であった（表 1 ).

\section{2. 治療成綨}

食道浸潤胃癌のらち左開胸開腹アブローチを施行し た組織学的 $\mathrm{ps}(+)$ （予後的漿膜因子陽性）胃癌を対象 に合切群と非合切群を比較検討した。 2 年生存率（以 下 2 生率とする) は合切群 $64.0 \%$, 非合切群 $41.8 \%$ と 合切群が良好で 3 年生存率（以下 3 生率とする）では ほとんど差は認めなかった。さらにps(+)群を stage III と stage IVに分け検討した結果, stage III では両

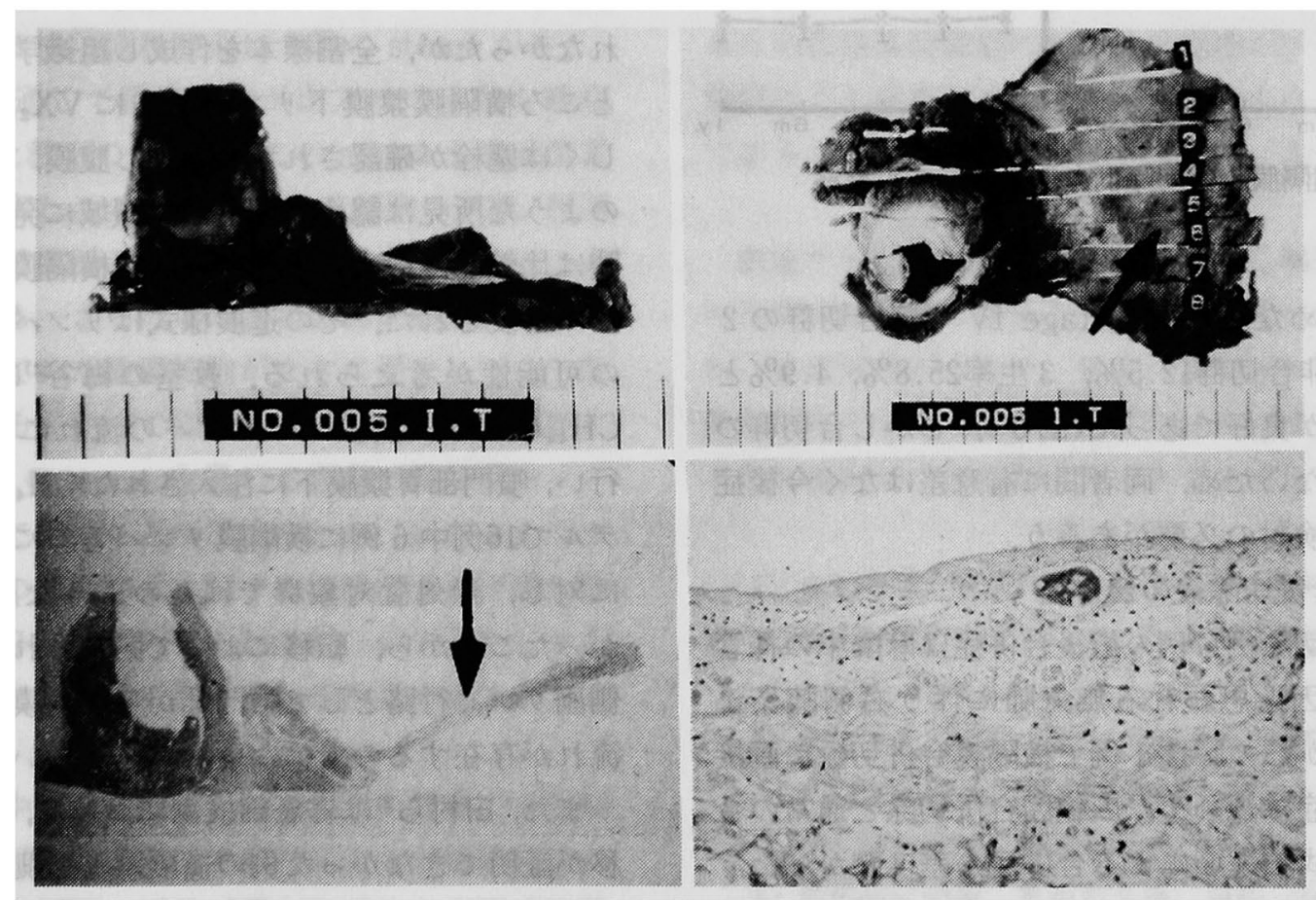

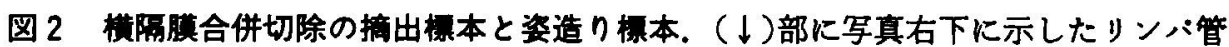
内への転移を認める $(\mathrm{HE} \times 100)$. 

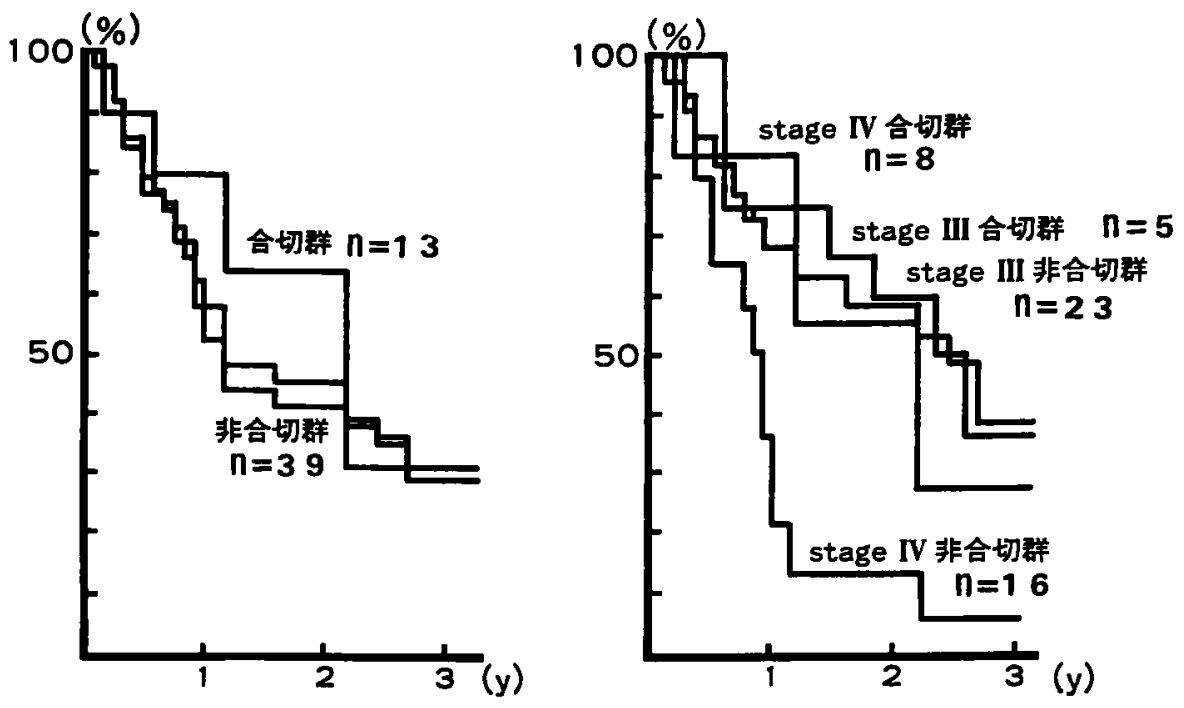

図 3 掼隔膜合併切除例の生存率
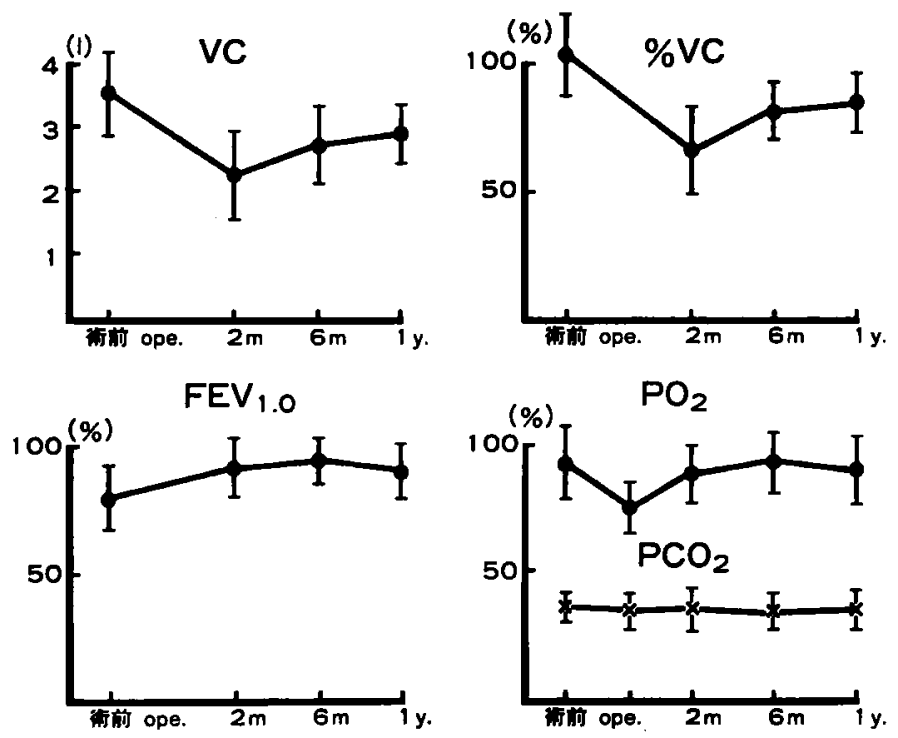

图4横隔㬴合併切除例の術後肺機能の推移

群間に差は認めなかったが stage IV では合切群の 2 生率 $55.6 \%$, 非合切群 $12.5 \%, 3$ 生率 $25.8 \%, 4.9 \%$ と 合切群の成績が良好であった(図 3). しかし合切群の 症例がまだ少ないため，両者間に有意差はなく今後症 例を増やし再恰討の必要があろう。

\section{3. 横隔膜合併切除後の合併症}

横隔膜合併切除例17例の術後合併症は麻酔中の插管 チューブが原因と思われる無気肺に伴ら右側肺炎 1 例, 膵切離端からの膵瘦 1 例で横隔膜合併切除に直接 起因する合併症は認めず，広範囲合併切除之通常の合 併切除など術式の違いによる合併症の差はなかった。 術後呼吸機能検査 VC, \%VC，に約20\%の低下はみら れたすのの正常域にとどまり，血液ガス $\left(\mathrm{Po}_{2}, \mathrm{Pco}_{2}\right)$
の値も術後明らかな変化はなく(図 4)，横隔膜切除範 囲の大小に上る検查値の有意な差は認めなかった。

\section{考察}

胃癌の横隔膜転移について桐本 ${ }^{61}$ は胃癌屍剖検例 100 例の検討で横隔膜転移は経腹膜性およびリンバ行 性に，また一部は直接浸潤性に形成されると述へてい る.われわれはこの事象を確認すへく経内視鏡的に $\mathrm{VX}_{2}$ 癌を噴門部に移植する噴門癌モデル2)を作成し， 横方向とくに横隔膜への転移様式について検討した。 その結果26例中 6 例は肉眼的にも明らかに横隔膜への 転移がみられ，また 4 例は肉眼的には転移は全くみら れなかったが，全割標本を作成し組織学的に検索した そころ横隔膜漿膜下リンパ管内に $\mathrm{VX}_{2}$ 腫瘍の浮遊も しくは塞栓が確認された。しかし腹膜, 腸間膜にはこ のような所見は認めず，噴門部領域に発生増殖した癌 腫は比較的早期に側方, すなわち横隔膜へ進展するこ とが示唆された，その進展様式はリンパ行性，播種性 の可能性が考えられる，教室の梅谷 ${ }^{2}$ は家鬼を用い $\mathrm{CH}_{44}$ による横隔膜へのリンパの流れについて検討を 行い, 噴門部胃漿膜下に注入された $\mathrm{CH}_{44}$ は，噴門癌モ デルで16例中 6 例に横隔膜リンバ管内に認められたの に対し，無処置対象群ではこのような所見は認めな かったことから，転移によって閉塞されたリンパ管の 側副リンパ行路として噴門部から横隔膜へのリンパ 流れが存在するのではないかと述べている。

また，田村ら》は胃癌剖検例において，腹膜播種性転 移が証明できなかった例の横隔膜胸腔側リンバ管内に 癌細胞の塞栓がみられたことより横隔膜へのリンバ行 性進展の可能性を示唆した，教室の吉田 ${ }^{8}$ は雑種成犬 
を用い裂孔部周辺の詳細なリンバ流を検索し，下部食 道および裂孔部食道からは横隔膜へ向からリンパの流 れは認めたが, 腹腔内の噴門部および腹部食道はむし ろ横隔膜笳性部から下降するリンパの流れを受けてお ク，正常状態でこの流れが逆行することはないとして いる.

従って，梅谷の論文2)で記されているように逆方向 すなわち腹部食道および噴門部から横隔膜へ向からり ンパの流れがあるとすれば缠瘍による側副リンパ行路 が出現してきたるのと考学る。このようなリンパ路閉 塞によるリンパ流の変化についての報告は諸家 ${ }^{910} に$ よりなされているが，西村9)は癌腫によるリンバ路の 通過障害のため，異常リンパ路の出見をきたし，ひい ては異常リンパ経路にあるリンパ節への転移を形成し てくると述べている。 また石榑10)はイ邓の胃リンバ路 を人工的にプロックするとその所属リンパ節へは流れ ないが，反対側および周囲のリンパ流は多くなってい ることを指摘している．噴門部のリンパ流に関して貴 志 ${ }^{11}$ ，川田 ${ }^{12}$ は噴門部からのリンパの流出路をブロッ クすることにより上行性のリンバ流の出現を認めるこ とを証明している，横隔膜リンパ管内への癌細胞の進 入経路として，も5一つ考えられるのは横隔膜腹腔側 に生ずる stoma（孔）を通じた腫湯細胞の侵入である. Remmale ら ${ }^{13)}$ は Ehrlich 腹水癌細胞をマウスの腹腔 内に注入し惹起される横隔膜の形態変化について走査 型電子顕微鏡を用いて検討したところ，腫場を注入し て24時間後には横隔膜腹腔面に多数の stoma が生じ, この stomaを通じて腫場細胞が出入りする像を観察

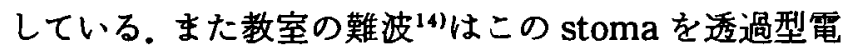
子䫒徽鏡で観察しこの stoma は中皮細胞の剥離, 脱落 および基底膜破壊がみられた篩状斑部に相当すること を証明している，さらにこの笠状斑部が横隔膜内リン ハ槽と直結しており腫場細胞がさに侵入していく像 をとらえている，従って臨床上, 胃漿膜面より䟝離し た癌細胞は，この stomaを通じて容易に横隔膜リンパ 槽内に進展していくことが示唆される。 以上の上うに 横隔膜への癌の進展様式に関する機序は直接浸潤を除 き，主にこの 2 経路が考えられるが，いずれにしても ある程度進行した癌腫に認められる所見であることは 間違いない。

しかし本文中に記したようにps（十）胃癌で 2 生率 の向上, stage IV 胃癌で 3 生率の向上など横隔膜合併 切除により生存期間の延長が得られており本術式の治 療効果は認め得るべきののであるうと考光る。それは
横隔膜を含め, 後腹膜を一塊として切除する本術式の 特徵から腹膜およびリンパ管内の顕性の転移巣を除去 しらること,ささらに横隔膜脚が切除され大動脈が充分 に露出されることにより周囲りンパ節の郭清が容易に かつ確実に行われることによるわのと思われる。しか し本術式の限界はあくまで片側横隔膜切除々考兄てい る.正岡は横隔膜弛緩症あるいは横隔膜麻疸について， 片側性横隔膜麻疩は成人では無症状のものが多く治療 の対象にならないが両側性横隔膜麻瘒の場合，換気能 力はその70\%を失い症状は著しく，著明な換気障害を 呈すると述べている. 教室例でも片側横隔膜合併切除 後の血液ガス，呼吸機能検查値，または臨床症状でと くに問題となるようなことはなかった。これは横隔膜 の機能が肋間筋による胸式呼吸で代償されているため であろらと考えられる。

また自験例における横隔膜切除後の再建法は横隔膜 弛緩症ないしは麻疸に利用される術式を採用しており 安全な方法といえる。片側横隔膜とくに左横隔膜の切 除を優先すべき理由は下横隔膜動脈に沿らリンパ流を 考慮したためである。下横隔膜動脈は腹腔動脈ないし 大動脈から左右 2 本分岐しており，横隔膜脚に接しな がら横隔膜へ向から。この左側下横隔膜動脈の噴門枝 は胃上部とは密接な関係にあり，同リンパ路の閉塞に よる側副リンパ行路が横隔膜左側ないし脚部に向か 5 ことが充分考えられる。 もら一つの理由は噴門部から の落鞈細胞に対して，右側横隔膜は肝が直下に位置す るため直接落䩗細胞に接する可能性が少なく，左侧横 隔膜の方が癌細胞の侵襲が容易であろうと考えたため であるがあくまで推論の域を脱していない.

\section{結 語}

教室で施行した食道浸潤癌に対する横隔膜合併切除 の治療成績とこの術式を選択する根拠について述べた が，また症例が少なく，適応，横隔膜の切除範用，切 除効果など明確な結論を出すには至らなかったが今後 さらに検討すべき課題であると考えている。

\section{文献}

1）村上吉博：噴門癌の実験的研究一噴門癌モデル作 成と転移形式について，久留米医会誌 49：1060 $-1067,1986$

2）梅谷博史，橋本 謙，松尾喬之他：噴門部リンバ流 に関する検討, 特に横隔膜を中心に, リンパ学 $10: 173-176,1987$

3）胃癌研究会編：胃癌取り扱い規約, 改訂第11版, 金 原出版, 東京, 1985 
4) Chin EF, Lynn RB : Surgery of the eventration of the diaphragm. J Thorac Surg $32: 6-14,1956$

5) Rives JD, Baker DD : Anatomy of the attachments of the diaphragm-Their relation to the problems of the surgery of diaphragmatic hernia. Ann Surg 115 : 745-755, 1942

6) 桐本孝次：胃癌原発巣と転移巣の組織形態学的視 覚考察, 大阪医会誌 $10: 1223-1231,1958$

7）田村鉀二, 海老原善朗：腹膜癌症の病理学的研究, 特に横隔膜リンパ管の特徵との関連, 東邦医会誌 $32: 502-508,1985$

8）吉田 力, 橋本 謙, 孝冨士喜久生他：噴門部リン ハ流の実験的研究，日外会誌 $90: 263,1989$

9）西村貞一：色素による生体胃および膵炡の淋巴道 の研究. 一局所色素注入による胃癌, 特に噴門癌の 淋巴道に関する研究一, 東北医誌 $53: 485$-495, 1956

10）石榑秀勝：胃癌におけるリンパ節転移と郭清に関
する臨床的実験的研究, 名古屋医 96：10-23, 1974

11）貴志周一郎：人食道，胃噴門部癌，区画性三淋巴 結節並二悪性腫湯転移形成に就イテ 2,3 人考察, 日外宝 $12: 862-877,1935$

12）川田彰得：噴門癌の食道進展に関する臨床的なら びに実験的研究一食道胃接合部ならびにその付近 における壁内リンパ路に関する実験的研究一，日 消外会誌 $7: 543-550,1974$

13) Remmele W, Richter IE, Wildenhof H : Experimentelle rastelektronen mikroskopische Resorption von Zellen aus dem Bauchraum. Untersuchungen zur Klin Wschr 53 : 913-922, 1975

14）難波雄一郎： $\mathrm{VX}_{2}$ 腫湯細胞の横隔膜播種性進展に 関する電子顕制的研究，日外会誌 $90 ： 1915$ $-1921,1989$

15) 正岡 昭：横隔膜麻瘏. 呼吸器外科学, 第 1 版, 南 山堂, 東京, 1987, p416-418

\title{
CLINICAL SIGNIFICANCE OF COMBINED RESECTION OF THE DIAPHRAGM IN THE TREATMENT OF GASTRIC CANCER WITH ESOPHAGEAL INVASION
}

\author{
Ken HASHIMOTO, Teruo KAKEGAWA, Jinryo TAKEDA, Takaho TANAKA, Kikuo KOFUJI, \\ Hisao IWAI, Kenji YASUMOTO and Shojirou YANO \\ First Department of Surgery, Kurume University School of Medicine
}

Since 1985, we have been performing an extensive combined resection of the unilateral diaphragm under left thoracotomy in cases of gastric cancer with esophageal invasion, involving invasion to the serosa without distant or disseminated metastasis. From 1976 to 1988, the resection was performed in 111 cases of upper gastric cancer with esophageal invasion. When classified by the approach route, there were 77 cases of left thoracoabdominal approach and mediastinal incision, and 34 of abdominal approach alone. Of the 77 cases of left thoracoabdominal approach, combined resection of the diaphragm was performed in 22 , and the surgical results were evaluated form 17 , after excluding 3 of only partial resection of the diaphragm, one of remnant gastric cancer and one of multiple cancer. The 2 year survival rates all ps $(+)$ cases were $64 \%$ for combined resection and $41.8 \%$ for non-combined resection. When classified by stage, the survival rates in stage IV cases were $55.6 \%$ for combined resection, and $12.5 \%$ for non-combined resection, showing a significant different. 